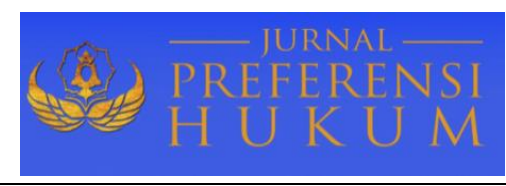

Jurnal Preferensi Hukum | ISSN: XXXX | E-ISSN: XXXX

Vol. 1, No. 2 - September 2020, Hal. 116-120| Available Online at https://www.ejournal.warmadewa.ac.id/index.php/juprehum

DOI: http://doi.org/10.22225/jph.v1i2.2348.116-120

\title{
PENGARUH SISTEM KARTEL TERHADAP STABILITAS PERSAINGAN USAHA DI INDONESIA
}

\author{
I Putu Ari Santika Putra, Ni Luh Made Mahendra Wati, I Nyoman Sutama \\ Fakultas Hukum Universitas Warmadewa, Denpasar-Bali, Indonesia
}

\begin{abstract}
Abstrak
Kartel merupakan perjanjian yang dibuat oleh pelaku usaha dengan pesaingnya untuk mendapatkan keuntungan secara berlebihan, yang tertuang dalam pasal 11 undang-undang No. 5 tahun 1999 tentang anti monopoli dan persaingan usaha tidak sehat di indonesia, pengaruh kartel dalam persaingan usaha dapat menyebabkan persaingan yang tidak sehat, merusak kestabilan pasar, dan menutup adanya persaingan dalam suatu pasar tertentu. Tujuan yang dikemukan dalam penelitian ini adalah untuk mengetahui bentuk-bentuk kartel yang biasanya terjadi dalam membatasi persaingan usaha tidak sehat di Indonesia, dan untuk mengetahui faktorfaktor yang digunakan oleh KPPU dalam mengidentifikasi indikator awal terjadinya sistem kartel. Penelitian ini menggunakan metode hukum normatif dengan rasionalitas yang akan mengkaji mengenai pengaruh sistem kartel terhadap stabilitas persaingan usaha di indonesia yang terlihat telah mengalami kekaburan norma. Sumber data yang digunakan dalam memecahkan masalah adalah pendekatan peraturan perundang-undangan. Literatur-literatur, jurnal-jurnal dan berbagai dokumen yang terkait. Hasil pembahasan menunjukan bahwa kartel memiliki beberapa jenis yaitu kartel daerah, produksi, harga, kondisi, pembagian laba, pengaruh sistem kartel dalam suatu persaingan usaha memiliki dampak negatif yang menyebabkan terjadinya persaingan usaha tidak sehat, serta merugikan berbagai pihak mulai dari pelaku usaha, konsumen, hingga pemerintah. Kemudian, dalam mengidentifikasi terjadinya kartel ada beberapa faktor yang di gunakan oleh KPPU yaitu faktor struktural yang terdiri atas tingkat konsentrasi pasar, jumlah perusahaan, ukuran perusahaan, homogenitas barang atau jasa, kontak multi pasar, persediaan serta kapasitas produksi, keterkaitan kepemilikan, kemudahaan dalam memasuki pangsa pasar tertentu, karakter permintaan. Faktor berikutnya adalah faktor prilaku yang di bagi menjadi dua bagian yang di mulai dari tranparansi dan pertukaran informasi.
\end{abstract}

Kata kunci: Bisnis; Kartel; Persaingan;

\begin{abstract}
A cartel is an agreement made by a business actor with its competitors to gain excessive profits, which is stated in article 11 of Law No. 5 of 1999 concerning anti-monopoly and unfair business competition in Indonesia, the influence of cartels in business competition can cause unfair competition, damage market stability, and shut down competition in a particular market. The objectives presented in this study are to determine the forms of cartels that usually occur in limiting unfair business competition in Indonesia, and to determine the factors used by KPPU in identifying early indicators of cartel systems. This study uses a normative legal method with rationality which examines the influence of the cartel system on the stability of business competition in Indonesia, which appears to have experienced norm blur. The data source used in solving problems is the statutory approach. Literatures, journals and various related documents. The results of the discussion show that cartels have several types, namely regional cartels, production, prices, conditions, profit sharing, the influence of the cartel system in business competition which has a negative impact which causes unfair business competition, as well as harms various parties ranging from business actors, consumers, to the government. Then, in identifying the occurrence of cartels, there are several factors used by KPPU, namely structural factors consisting of the level of market concentration, number of companies, company size, homogeneity of goods or services, multi-market contacts, supply and production capacity, ownership linkages, ease of entry. specific market share, the character of demand. The next factor is the behavioral factor which is divided into two parts, starting from transparency and information exchange.
\end{abstract}

Keywords: Business; Cartel; Competition. 


\section{PENDAHULUAN}

Kartel merupakan perjanjian atau kesepakatan yang di lakukan oleh pelaku usaha dengan persainganya dengan tujuan untuk mendapatkan keuntungan secara berlebihan. Menurut ketentuan pasal 11 undang-undang no. 5 Tahun 1999 tentang praktik monopoli dan dan persaingan usaha tidak sehat, perjanjian tersebut di buat oleh pelaku usaha dengan pesaingnya yang bermaksud untuk mempengaruhi harga dan mengatur produksi dengan mengatur produksi atau pemasaran suatu barang atau jasa, sehingga dapat mengakibatkan terjanya praktik monopoli atau persaingan usaha tidak sehat. Ada beberapa unsur yang harus di buktikan oleh komisi pengawasan persaingan usaha (KPPU) Terkait dengan pelanggaran pasal 11 undang-undang No. 5 tahun 1999 tentang praktik monopoli dan pesaingan usaha tidak sehat. Pertama, keberadaan perjanjian yang di lakukan oleh para pelaku usaha tersebut berkolusi yang merupakan bukti utama atau direct evidence di mana para pelaku usaha saling berkoordinasi untuk mempengaruhi pemasaran barang atau jasa. Kedua, konspirasi antar pelaku usaha untuk mempengaruhi pemasaran barang atau jasa. Ketiga, pelaku usaha memanipulasi data keuangan, produksi, pemasaran suatu barang yang menjadikan suatu data fiktif agar dapat terhindar dari indikasi terjadinya kartel dalam suatu perusaaan sehingga pihak berwenang sulit untuk mengidentifikasinya (Ibrahim, 2007).

Pada kondisi normal, jika direct evidence di peroleh maka akan tidak sulit untuk pembuktianya. Akan tetapi menjadi sulit jika tidak di temukan perjanjian ataupun dokumen yang menujukan adanya kesepakatan yang di buat oleh para pelaku usaha, yang di mana kartel dapat menimbulkan dampak berupa terjadinya praktik monopoli dan tercerai berainya persaingan usaha sehat. Dampak ini dapat merugikan konsumen, pemerintah, serta pelaku usaha itu sendiri (Usman, 2004). Ada beberapa isu terkait kartel antara lain sulitnya pembuktian tentang adanya perjanjian kartel. Walaupun perjanjian kartel sudah disinyalir keberadaanya tetapi, cukup sulit bagi komisi pengawas persaingan usaha (KPPU) untuk dapat menemukan alat bukti adanya perjanjian kartel tersebut (Antoni, 2019). Hal ini di karenakan pada perkembanganya pelaku usaha dan pesaingnya mengadakan kesepakatan antara mereka (cartelist) secara tidak tertulis, sehingga KPPU mendapakan kendala dalam menemukan alat bukti yang telah dilakukannya perjanjian.

Isu lain adalah penilainya terhadap kartel tidak semudah kata-kata yang tertuang dalam ketentuan hukum yang mengaturnya. Dalam praktiknya, fakta yang secara normatif yuridis sudah termasuk katagori kartel seringkali secara praktis ekonomis belum merupakan kartel begitupun sebaliknya, prilaku yang terkesan legal menurut hukum (de jure), ternyata secara fakta (de facto) sudah merupakan prilaku kartel (Fitriyah \& Sulistiyono, 2018). Fenomena di atas memerlukan pembahasan lebih lanjut, terutama terkait pembuktian unsur-unsur kartel dalam rangka penegakan hukum kartel penilaian terhadap eksistensi kartel dalam praktiknya, sekaligus dampak kartel tehadap persaingan usaha di Indonesia (A, 2012; Anggraini, 2013).

Berdasarkan uraian di atas, maka penelitian ini bertujuan untuk mengetahui bentuk-bentuk kartel yang biasanya terjadi dalam membatasi persaingan usaha tidak sehat di Indonesia serta untuk mengetahui faktor-faktor yang di gunakan oleh KPPU dalam mengidentifikasi indikator awal terjadinya sistem kartel.

\section{METODE PENELITIAN}

Adapun tipe penelitian yang digunakan adalah tipe penelitian hukum normatif, yaitu dengan melakukan pendekatan perundang-undangan yang meliputi hukum positif seperti perundanganundangan yang berkaitan dengan pengaruh sistem kartel tehadap stabilitas persaingan usaha di Indonesia (Utari et al., 2017), yang mana memiliki kekaburan norma dalam pasal 11 undang-undang no. 5 tahun 1999 tentang praktik monopoli dan persaingan usaha tidak sehat. Dalam praktik penilaian serta pembuktian kartel yang secara fakta normatif yuridis merupakan kartel namun secara ekonomi belum merupakan kartel begitu pun sebaliknya. Adapun sumber data yang digunakan yaitu bahan hukum primer yang artinya bahan hukum yang berpusat pada peraturan UU yang berlaku di Indonesia, dan bahan hukum sekunder yaitu bahan hukum yang diperoleh dari pengkajian kepustakaan. Bahan hukum yang telah dikumpulkan selanjutnya diolah menggunakan metode deduktif induktif atau sebaliknya, untuk memperoleh bahan hukum yang berkualitas sesuai dengan pokok masalah yang dibahas dan akhirnya berdasarkan bahan hukum yang diperoleh dari pengumpulan maupun pengelolaan-pengelolaan tersebut di atas lalu disajikan dalam bentuk jurnal secara deskriptif. 


\section{HASIL DAN PEMBAHASAN}

\section{Bentuk-Bentuk Kartel yang Terjadi dalam Persaingan Usaha Tidak Sehat di Indonesia}

Dalam persaingan usaha di indonesia terdapat tindakan-tindakan ilegal yang dilakukan oleh pelaku usaha untuk mendapakan keuntungan berlebih dalam melakukan bisnis/usaha yang di lakukan oleh pelaku usaha, yang di mana memiliki dampak negatif bagi konsumen yaitu salah satunya praktik monopoli dalam mejalankan suatu bisnis/ usaha dalam persaingan usaha di mana praktik monopoli bersifat menekan suatu persaingan dan meningkatkan keuntungan bagi pelaku usaha. Maka dalam praktik monopoli tersebut memiliki bentuk-bentuk serta dampak yang mengakibatkan kerugian bagi konsumen, produsen, serta pemerintah, dalam kasusnya praktik monopoli sulit untuk di ungkap di karenakan sulitnya mendapatkan bukti-bukti dan keterangan dari berbagai sumber yang dapat mempermudah menganalisa terjadinya praktik monopoli, dalam hal ini praktik monopoli dapat mempengaruhi suatu perekonomian dalam suatu Negara (Usman, 2004).

Dalam perjanjian kartel terdapat kegiatan yang di sepakati oleh angota cartelist yang mengatur perdagang bisnis dan wilayah pemasaran, setiap pelaku usaha yang bersama melakukan prilaku kartel memiliki jenis dari kartel yang di sepakati bersama. Setiap kesepakatan yang digunakan tentu berpengaruh pada perekonomian serta pangsa pasar yang di miliki pelaku usaha yaitu dalam kesepakatan kartel sebagai berikut:

1. Kartel daerah cakupan prilaku kartel ini mengenai wilayah pemasaran dalam daerah tertentu, yang mempunyai pangsa pasar tersendiri oleh pelaku usaha yang melakukan perjanjian kartel agar tidak masuknya pesaing baru ke wilayah yang di sepakati oleh para anggota kartel.

2. Kartel produksi merupakan kartel yang memalui kesepakatan dari pelaku usaha yang melakukan perjanjian kartel dengan mengatur kuota produksi serta pengaturan output ke pemasaran agar mempunyai dampak ke harga suatu barang atau jasa yang di tawarkan ke konsumen.

3. Kartel harga merupakan kartel yang melalui pengamatan pangsa pasar yang terus meningkat sehingga dengan dilakukan penetapan harga (price fixing) yang sudah di sepakati oleh anggota kartel. Untuk meniadakan persaingan dalam pangsa pasar suatu barang atau jasa tertentu.

4. Kartel kondisi merupakan kartel dalam suatu kondisi tertentu misalnya melakukan administrasi, kredit, atau promo yang di di tetapkan secara bersama-sama anggota kartel agar terhindar dari persaingan atau meniadakan persaingan yang menjadi kerugian bagi konsumen dikarenakan tidak adanya harga serta persaingan yang kompetif.

5. Kartel pembagian laba merupakan pembagian keuntungan bagi anggota kartel dalam menjalankan kesepakan serta aturan yang di sepakati bersama. serta sebagai kompensasi yang bertujuan untuk meningkatkan loyalitas kepada anggo kartel yang menyetujui perjanjian.

Dalam praktiknya kartel tidak saja di lakukan dengan satu jenis kartel, namun bisa saja di lakukan dengan ke 5 jenis kartel. Yang tidak lain bertujuan memperkecil persaingan serta pengwasaan pangsa pasar barang atau jasa tertentu. Sehingga penimbulkan terjadinya persaingan usaha tidak sehat di indonesia yang dimana mempunyai pangsa pasar yang cukup besar (Nugroho, 2004).

\section{Faktor-Faktor yang Digunakan oleh KPPU dalam Mengidentifikasi Indikator Awal Terjadinya Sistem Kartel}

Dalam mengidikasikan pelaku usaha melakukan prilaku kartel maka di perlukannya peranan dari KPPU (Komisi Pengawasan Persaingan Usaha) dalam menegakan hukum persaingan di indonesia sebagai lembaga yang berwenang mengawasi setiap kondisi persaingan serta tindakan yang di larang dalam pasal 4 sampai 18 Undang- Undang no. 5 tahun 1999 tentang anti monopoli dan persaingan usaha tidak sehat di Indonesia. Mengidentifikasikan prilaku kartel dalam suatu persaingan memiliki indikator awal dalam menentukan suatu pelaku usaha melakukan perjanjian kerja sama antara pesainganya dengan produk yang sejenis yang memiki tujuan ingin mengatur harga, peningkatan harga, pengwasaan pasar tertentu, menghambat pesaing baru untuk masuk dalam pangsa pasar. Kebanyakan otoritas persaingan usaha dalam berbagai negara sangat berhati hati dalam menentukan suatu indikasi terjadinya kartel dalam suatu persaingan dalam melakukan pembuktian prilaku kartel yang mana perbedaanya yang sangat tipis dalam persaingan usaha yang sehat berlangsung seperti harga yang paralel (price pararellelism) sering di anggap tindakan yang di lakukan secara bersama sama secara kolusif untuk menentukan suatu harga (fixing price) oleh para 
anggota kartel (Risnain, 2015). Banyaknya penyebab terjadinya suatu paralelism yang dimana persaingan dalam pasar kompetitif, maka faktor yang menjadi indikator awal terjadinya sistem kartel dalam suatu persaingan tidak sehat di Indonesia. Menurut KPPU (Komisi Pengawasan Persaingan Usaha) faktor strukturnal dan faktor prilaku yaitu sebagai berikut:

1. Faktor struktural

a. Tingkat konsentrasi suatu pangsa pasar terpusat dalam beberapa pelaku usaha yang memiliki posisi dominan dalam suatu pangsa pasar tertentu.

b. Jumlah perusaha yang bersaing dalam suatu pangsa pasar tertentu memiliki jumlah yang tidaklah lumayan banyak namun dalam masuknya pesaing baru sulit masuk dalam pangsa pasar tertentu.

c. Ukuran perusahaan, apakah nilai suatu perusahaan memliki investasi yang besar dan memiliki pengaruh dalam suatu pangsa pasar tertentu.

d. Homogenitas barang atau jasa. Barang atau jasa yang memiliki sifat yang sama serta kegunaan yang sama.

e. Kontak multi pasar. Memiliki jaringan pasar yang cukup luas dari pengaturan pasar dari masing-masing pelaku usaha.

f. Persediaan serta kapasitas produksi. Mengatur persediaan barang atau jasa serta output pemasaran yang dapat membuat kelangkaan.

g. Keterkaitan kepemilikan. Memiliki keterkaitan dalam pengwasaan pangsa pasar secara bersama-sama oleh pelaku usaha yang melakukan perjanjian kartel.

h. Kemudahaan dalam memasuki pangsa pasar tertentu. Kemudahan bagi anggota kartel (cartelist) dalam pengwasaan pangsa pasar karena pengaturan antara pelaku usaha yang di ajak melakukan perjanjian kartel.

i. Karakter permintaan, memiliki permintaan yang tinggi namun seberapa pun kenaikan harga yang di tetapkan oleh pelaku usaha tidak berpengaruh kepada konsumen.

2. Faktor prilaku.

a. Tranparansi. Keterbukaan serta pertanggungjawaban data yang di berikan oleh pelaku usaha yang di manipulasi data agar dapat terhindar dari pajak dan administrasi lainya yang dapat merugikan pemerintah.

b. Pertukaran informasi. Pengaturan data antara anggota kartel (cartelist) mengenai informasi tentang produksi, harga, pemasaran. Indikator awal terjadinya kartel memiliki 2 faktor yaitu secara struktural dan secara prilaku yang ada dalam Undang-undang no. 5 tahun 1999 tentang anti monopoli dan persaing usaha tidak sehat di indonesia. Naiknya persaingan menimbulkan dua sisi negatif dan positif dalam suatu pangsa pasar tertentu, peningkatan suatu perekomian sangat berpengaruh pada kesejahtraan (Waluyo, 2002).

\section{SIMPULAN DAN SARAN}

\section{Simpulan}

Berdasarkan uraian di atas, disimpulkan bahwa kartel sendiri memiliki beberapa bentuk yang di mana memiliki maksud dan tujuan yang berbeda-beda yaitu mulai dari kartel daerah, kartel produksi, kartel harga, kartel kondisi dan kartel pembagian laba yang di mana sama-sama merugikan baik itu pihak konsumen, pelaku usaha atau pun pemerintah, yang menjadikan suatu perekonomian tidak stabil. Maka dalam sistemnya kartel bergerak secara terorganisir yang tergabung dalam beberapa perusahaan, yang memiliki satu tujuan yang sama yaitu mendapatkan keutungan secara berlebihan dan pangsa pasar yang stabil serta menghindari terjadinya suatu persaingan keras antar pelaku usaha dan menghambat adanya pelaku usaha baru yang ingin masuk dalam suatu pangsa pasar tertentu. Sehingga terdapat kondisi-kondisi yang menyebabkan terjadinya kartel dalam suatu persaingan usaha tidak sehat yaitu dari jumlah pelaku usaha yang relatif sedikit, produk yang bersifat homogen, elastisitas permintaan terhadap produk, melakukan kecurangan baik data, pemasaran, produk, serta kartel berkembang dalam sektor bisnis yang memiliki nilai investasi besar. Kemudian, Faktor-faktor yang digunakan oleh KPPU dalam mengidentifikasi indikator awal terjadinya sistem kartel yaitu pertama faktor struktural yang di bagi menjadi beberapa bagian yang di mulai dari tingkat konsentrasi pasar, jumlah perusahaan, ukuran perusahaan, homogenitas barang atau jasa, kontak multi pasar, persediaan serta kapasitas produksi, keterkaitan kepemilikan, 
kemudahaan dalam memasuki pangsa pasar tertentu, karakter permintaan. Faktor kedua adalah faktor prilaku yang di bagi menjadi dua bagian yang di mulai dari tranparansi dan pertukaran informasi.

\section{Saran}

Berdasarkan hasil penelitian yang telah dijabarkan di atas, hendak pula disampaikan beberapa saran kepada berbagai pihak yakni, bagi pemerintah: perlunya peningkatan kinerja KPPU dalam mengawasi persaingan usaha di Indonesia, yang di harapkan dapat memberikan keadilan bagi seluruh masyrakat Indonesia. Selanjutnya, bagi masyarakat: perlunya masyarakat memahami bahwa ekonomi di dasari dari perkembangan usaha, persaingan yang baik, dan akses yang memadai, pemerintah hanya bisa mengawasi dan meberikan fasilitas yang mempuni sehingga kita sebagai masyarakat dan juga bagian dalam memajukan perekonomian di indonesia patut bersama-sama mengawasi dan mengintrofeksi diri untuk bisa berkembang memajukan bangsa kita ke arah yang lebih baik, dan memulai memproduksi serta mecintai produk-produk dalam negeri untuk mendukung perkembangan industri di indonesia. Yang terakhir, bagi pengusaha Indonesia: jangan pernah berputus asa, terus berkarya dan mengembangkan diri, jujur adil dan berjiwa tangguh serta jangan pernah patah semangat jadilah pengusaha yang kreatif dalam mengembangan ekonomi kreatif, untuk menciptakan persaingan Usaha yang kompetitif demi keadilan sosial bagi seluruh masyrakat Indonesia.

\section{DAFTAR PUSTAKA}

A, S. P. (2012). Hukum Meger Indonesia dalam Konteks Hukum Persaingan Usaha. CR Publishing.

Anggraini, A. M. T. (2013). Penggunaan Bukti Ekonomi dalam Kartel Berdasarkan Hukum Pesaingan Usaha. Jurnal Hukum Prioris, 3(3), 1-25.

Antoni, V. (2019). Penegakan Hukum atas Perkara Kartel di Luar Persekongkolan Tender di Indonesia. Mimbar Hukum, 31(1), 95-111.

Fitriyah, S., \& Sulistiyono, A. (2018). Analisis Yuridis dan Penggunaan Indirect Evidence dalam Kasus Kartel Sepeda Motor di Indonesia Ditinjau dari Hukum Persaingan Usaha Indonesia. PRIVAT LAW, 6(1), 34-45.

Ibrahim, J. (2007). Hukum Persaingan Usaha. Bayu Media Publishing.

Nugroho, S. A. (2004). Hukum Persaing Usaha di Indonesia dalam Teori dan Praktik Serta Penerapan Hukumnya. Kencana Prenadamedia Group.

Risnain, M. (2015). Aspek-Aspek Hukum Peningkatan Daya Saing dalam Industry Perdagangan Bebas. Keni Media.

Usman, R. (2004). Hukum Persaingan Usaha di Indonesia. PT Gramedika utama.

Utari, R. H. J., Praningtyas, P., \& Njatrijani, R. (2017). Analisa Yuridis tentang Pelanggaran Pasal 11 Undang- Undang Nomor 5 Tahun 1999 tentang Larangan Praktek Monopoli dan Persaingan Usaha Tidak Sehat Dalam Perdagangan Sapi Impor di Indonesia. Diponegoro Law Journal, $6(2), 1-13$.

Waluyo, B. (2002). Penelitian Hukum dalam Praktek. Sinar Gratika. 